\title{
International Legal Instruments in Responding to Human Trafficking
}

\author{
Ridwan Arifin* \\ Universitas Negeri Semarang, Indonesia \\ Yehezkiel Lemuel \\ Universitas Negeri Semarang, Indonesia
}

\author{
Ngaboawaji Daniel Nte \\ Novena University, Nigeria
}

\begin{abstract}
Human trafficking grows and develops rapidly, with various motives and types of crimes. Various obstacles are faced in handling human trafficking cases, ranging from inadequate legal instruments to weak law enforcement. This study overviewed the international legal instrument on human trafficking cases, following the identification of the recent forms and issues in enquiring how international legal instruments deal with human trafficking. This study used legal research method by referring to international laws as the source of law in compiling this human trafficking research. This study found that various instruments and international cooperation have dealt with human trafficking cases. However, in various related studies, these different legal instruments did not have a clear and binding force when the issue occurs in the domestic state. In addition, human trafficking in various legal instruments also had many types, and all of them are interrelated. This study highlighted and concluded that in making various international legal instruments effective in this case, more intensive international cooperation was needed, both regionally and globally.
\end{abstract}

KEYWORDS: Human Trafficking, Labor Human Rights, Criminal Law.

Copyright (C) 2021 by Author(s)

This work is licensed under a Creative Commons Attribution-ShareAlike 4.0 International License. All writings published in this journal are personal views of the authors and do not represent the views of this journal and the author's affiliated institutions.

\section{HOW TO CITE:}

Arifin, Ridwan, et al., "International Legal Instruments in Responding to Human Trafficking" (2021) 8:3 Lentera Hukum 417-446. DOI: <https://doi.org/ 10.19184/ejlh. v8i3.22137>.

Submitted: 19/01/2021 Reviewed: 08/02/2021 Revised: 26/11/2021 Accepted: 29/11/2021

\footnotetext{
* Corresponding author’s e-mail: ridwan.arifin@mail.unnes.ac.id
} 


\section{INTRODUCTION}

Historically, human trafficking has become part of the inhumane history, and it remains a prevalent practice but the most critical problem. Today, human trafficking has been considered a form of modern slavery. ${ }^{1}$ According to the United Nations (UN), human trafficking is an act of recruiting, sending, moving, holding, or receiving someone with threats, use of force, slavery, coercion, debt bondage, or other forms of fraud for exploitation. ${ }^{2}$ In many cases, human trafficking is always accompanied by other crimes such as people smuggling, document falsification, and torture. Interpol confirmed that the authorities rescued 430 human trafficking victims and identified 4,000 as irregular migrants originating from 74 different countries. ${ }^{3}$ According to the FBI, human trafficking can vary and grow over time, from sex trafficking, labor trafficking, and domestic servitude. ${ }^{4}$

In particular, human trafficking is commonly different from other crimes. It profoundly impacts other human beings as victims entangled in it because it does not consider the rights related to human rights violations. ${ }^{5}$ As a result, human trafficking has become one of the five most significant crimes globally. It is as high as drug trafficking, illegal arms trade, crimes in

1 Novianti. "Tinjauan Yuridis Kejahatan Perdagangan Manusia (Human Traffikking) sebagai Kejahatan Lintas Batazzs Negara" (2014) 5:2 Jurnal Ilmu Hukum Jambi. See also Anggie Rizqita Herda Putri \& Ridwan Arifin, "Perlindungan Hukum Bagi Korban Tindak Pidana Perdagangan Orang di Indonesia" (2019) Res Judicata 2:1: 170185.

2 Lourensy Varina Sitania \& Eko Suponyono, "Akomodasi Pemberantasan Tindak Pidana Perdagangan Orang dalam Aspek Hukum Internasional dan Nasional" (2020) 2:1 Jurnal Pembangunan Hukum Indonesia 38-54.

3 Online Interpol International, "286 arrested in global human trafficking and migrant smuggling operation", online: <https://www.interpol.int/news-and-events/news/ 2021 /286-arrested-in-global-human-trafficking-and-migrant-smuggling-operation >.

4 FBI, "Human Trafficking," online: <https:/www.fbi.gov/investigate/violent-crime/ human-trafficking>. See also Ella Cockbain \& Kate Bowers, "Human Trafficking for Sex, Labor, and Domestic Servitude: How Do Key Trafficking Types Compare and What are Their Predictors?" (2019) 72:1 Crime, Law, and Social Change 9-34.

5 UNHR, Human Rights and Human Trafficking" United Nations (New York: UNHR, 2014). See also UNODC, "An Introduction to Human Trafficking: Vulnerability, Impact, and Action (New York: United Nations, 2008). 
intellectual property rights, and money laundering. ${ }^{6}$ The rationale of this categorization considers the UN Office's report on Drugs and Crime (UNODC) in 2010 that human trafficking has steadily increased at the international level. ${ }^{7}$ There were around 800.000 people trafficked every year, spreading across countries; 40.3 million people worldwide were victims of human trafficking. ${ }^{8}$ They were sold, bought, shipped, and forced to work by certain parties, and 10 million of them were children. ${ }^{9}$ This amount significantly increased as released by the UNODC in 2020. More than 1.000 .000 people have become victims of human trafficking, including men, women, boys, and girls. ${ }^{10}$

Those affected by this problem are from emerging countries because of various sectors. These sectors are the state condition under national security and political stability, making emerging countries easy targets for human trafficking activities. ${ }^{11}$ While countries are inseparable from human trafficking, each country can be a transit point or destination for marketing human trafficking victims; most come from emerging countries. ${ }^{12}$ The United States is evidenced as a developed country with the largest market for human trafficking. The latest data from the National Human Trafficking Hotline of the United States in 2021 also released that 63,380 human trafficking cases were reported in December 2007. ${ }^{13}$ From 2016 until mid-2019, there were 4,906 cases of human trafficking in Indonesia. ${ }^{14}$

6 Eva Arief, "Relevansi Hukum Pidana Internasional dalam Menganalisis Kasus Perdagangan Manusia Khususnya Wanita dan Anak-Anak, Sebagai Salab Satu Jenis Kejahatan Transnasional" (2016) 4:1 Hukum dan Dinamika Masyarakat 89-97.

7 UNODC, Global Report on Trafficking in Persons 2020 (New York: UNODC, 2020).

8 Refworld, "UN Office on Drugs and Crime Global Report," online: <https://www. refworld.org/publisher,UNODC,,IND,,0.html>.

9 Ibid.

10 UNODC, supra note 7.

11 Beth A. Simmons, et al., "The Global Diffusion of Law: Transnational Crime and the Case of Human Trafficking" (2018) 72:2 International Organization 249-281.

12 Ibid.

13 Polaris, "US National Human Trafficking Hotline", online: <https://polarisproject.org/ resources/us-national-human-trafficking-hotline-statistics/ $>$.

14 US Embassy, "2020 Trafficking in Persons Report", online: <https://id.usembassy.gov/ our-relationship/official-reports/2020-trafficking-in-persons-report/>. See also Yuda Prasetya, "Legal Analysis of Human Trafficking Case as A Transnational Organized 
The highest number of victims were children and toddlers where it increases each year. Even in 2020, according to the International Organization for Migration (IOM), trafficking in Indonesia rose to 154 cases. The majority of victims of exploitation received by IOM throughout 2020 were sexual exploitation. ${ }^{15}$

The profits generated from human trafficking activities are also not relatively small. It can create more than 150 billion dollars originating from human trafficking actions, ${ }^{16}$ such as sex trafficking, forced labor, and debt bondage, making the three types of human trafficking actions a source of income that is bigger or more profitable than other kinds of human trafficking. It is not surprising that several parties are still carrying out human trafficking due to these huge profits. ${ }^{17}$ This crime also has an enormous impact on economic, political, cultural, and humanitarian aspects. This crime must immediately be tackled and eradicated from the community both on a national and international scale to ensure the general public's safety and human rights for every humankind. ${ }^{18}$

Given human trafficking actions regardless of age, race, nationality, and gender, all people in this world can be victims of human trafficking without any exceptions for certain people. There are three elements in human trafficking, including recruiting, kidnapping, and transferring the victim. They also cover means in the stage of force, kidnapping, and frauding the victim. The last element is the purpose of exploitation, which protects human trafficking actions (for instance, sexual exploitation, forced labor, and human organ trafficking). ${ }^{19}$

Crime That is Threatening State Security" (2020) 4:1 Lex Scientia Law Review 143150.

15 Republika Online, "Kasus Perdagangan Orang di Indonesia Naik Pada 2020", online: <https://www.republika.co.id/berita/qr7v11330/kasus-perdagangan-orang-diindonesia-naik-pada-2020>.

16 ILO, Global Estimates of Modern Slavery: Forced Labour and Forced Marriage (Geneva: International Labour Office, 2017).

17 Hakemli Dergi, Galatasaray Üniversitesi Hukuk Fakültesi Dergisi (Istambul: Beta Basim Yayim Dağitim, 2019).

18 Jackie Jones \& John Winterdyk, "Introduction Human Trafficking: Challenges and Opportunities for the 21st Century" (2018) 8:1 Oñati Socio-Legal Series 1-10.

19 Ella Cockbain \& Kate Bowers, supra note 4. 
Several factors can influence human trafficking. The first is the poverty that exists in the community. Economic reasons strongly influence human trafficking, especially for the poor in underdeveloped and developing countries. The second factor is a large population in a country, which is also correlated with the first. With a large population in most underdeveloped and developing countries, the existing job opportunities cannot accommodate all. The third is the patriarchal culture, which is still attached and valid in several global south countries. The patriarchal culture only gives benefits to men as the most favored gender in society.

On the contrary disadvantages women because of their lower position than men, resulting in pressure in society. Therefore, women are easier to become the human trafficking target than men. It encourages women, as the victims of human trafficking, to be sold or sent to prostitution..$^{20}$

In practice, the parties or persons that commit human trafficking use several ways in doing its deeds. For example, the perpetrators kidnap and sell the victim for prostitution that operates outside the jurisdiction. Otherwise, the perpetrator tricks victims into getting a job in a certain good workplace, but they subsequently end up being put in or sold into prostitution. ${ }^{21}$ Also, some victims are sold by the family with a belief of being employed as servants or households. However, they often experienced contract marriage with an unknown person. Such a practice in human trafficking result from the development of technology and information, evolving into more sophisticated ways to convince victims. ${ }^{22}$

Some impacts are caused by human trafficking actions, such as psychological impact, social impact, and physical health impact. As mentioned before, women are more vulnerable to becoming victims of human trafficking than men, making women also tend to have the worse effect caused by human trafficking. Women's psychological impact as the

20 Paul Harpur \& Heather Douglas, "Disability, Domestic Violence, and Human Rights." In: Reilly N. (eds), International Human Rights of Women (Singapore: Springer, 2019).

21 Frida Högfors, "Human Trafficking International Law and the Regulation of Sexual Exploitation of Women on the Internet" (2020) Student Thesis, Örebro University, School of Law, Psychology and Social Work.

22 Ibid. 
victims of human trafficking usually includes disturbance, phobia, confusion, panic attack, fear, and disorientation. Some of these things can be caused by female victims who are always socially isolated, confined, and physically threatened. ${ }^{23}$ The social impact is also caused by the isolation from the social life experienced by the victim. It can cause the female victim to be isolated if she returns to society and loses the meaning and purpose of life, which mostly ends in committing suicide. ${ }^{24}$ All-female human trafficking victims experience the impact of physical health itself. Most of them experience physical and sexual violence every day according to the type of human trafficking they experience. ${ }^{25}$ Coupled with the victims who are not given access to health, their bodies are very vulnerable to disease. The disease itself includes physical injuries from torture as well as sexually transmitted infections resulting from sex trafficking.

Some previous studies emphasized that law enforcement and the protection of human trafficking cases still faced many challenges. One of which is the weakness in the implementation of international legal policies in this case. ${ }^{26}$ Instead, this study explicitly analyzes various international legal instruments in dealing with human trafficking cases, both in the context of international law and international cooperation. Crimes against human trafficking have been regulated in various international legal instruments. ${ }^{27}$

23 Tiffany Dovydaitis, supra note 23.

24 Jane Gillette, "Human Trafficking" (2012) 143:8 Journal of the American Dental Association 830.

25 Tiffany Dovydaitis, supra note 23.

26 Nadine Blom, "Human Trafficking: An International Response." In: Winterdyk J., Jones J. (eds), The Palgrave International Handbook of Human Trafficking (Cham: Palgrave Macmillan, 2020). See also Janie Chuang, "Exploitation Creep and the Unmaking of Human Trafficking Law" (2014) 108:4 American Journal of International Law 609-649.

27 These instruments range from the International Agreement for the Suppression of White Slave Traffic of 1904, International Convention for the Suppression of White Slave Traffic of 1910, International Convention for the Suppression of White Slave Traffic of 1921, International Convention for the Suppression of Traffic in Women and Children of 1921, International Convention for the Suppression of Traffic in Women of Full Age of 1933, Convention on the Elimination of All Form of Discrimination against Women (CEDAW) of 1979, International Convention on the Rights of the Child, ILO Convention No. 182 Concerning the Prohibition and 


\section{METHODS}

This study used legal research by analyzing norms following its practices on human trafficking, with further references to Indonesian regulations and international instruments. The data on human trafficking was obtained from the UNODC Global Reports, the International Organization for Migrants (IOM) Report, and the Indonesian government. They were Human Rights Law, Ant-Human Trafficking Law, Women and Children Protection Law, and some international legal instruments, such as the UN Convention against Transnational Organized Crime (2000), the ILO Forced Labour Convention (Convention No. 29 of 1930), ILO Abolition of Forced Labour Convention (Convention No. 105 of 1957), the Slavery Convention (1926), the UN Convention for the Suppression of the Traffic in Persons and the Exploitation of the Prostitution of Others (1949), the Convention on the Elimination of All Forms of Discrimination against Women, Universal Declaration of Human Rights (UDHR), and the International Covenant on Civil and Political Rights (ICCPR).

\section{HUMAN TRAFFICKING: RECENT FORMS AND ISSUES}

Cases of human trafficking from day to day continue to develop, ranging from motives, perpetrators, and the form of the crime itself. Harkristuti Harkriswono-Indonesia's leading criminal law expert-emphasized several forms of human trafficking. First, sending workers from a certain country to another country abroad without official documents or official documents that have been falsified for these workers using legal reasons like cultural missions. ${ }^{28}$ Second, the placement of domestic workers in the country for

Immediate Action for the Elimination of the Worst Forms of Child Labor, UN Protocol against Transnational Organized Crime of 2000, and also Palermo Protocol of 2000 (Protocol to Prevent, Suppress and Punish Trafficking in Persons).

28 Endah Sundari, Analisis Yuridis Terhadap Bali Declaration on People Smuggling, Trafficking in Persons And Related Transnational Crime Sebagai Salab Satu Bentuk Perjanjian Internasional (2017) Student Thesis, Universitas Sumatera Utara Faculty of Law. Human trafficking is understood as the recruitment, transfer, sheltering, or receipt of persons, through the threat or use of force or other forms of coercion, abduction, deception, deception, or the abuse of power or a position of vulnerability or the giving or receiving of payments or benefits to obtain the consent of a person 
sexual exploitation. ${ }^{29}$ Third, time-limited marriages are implemented only to legalize sexual intercourse meant for a specific period to receive financial compensation (contract marriage). ${ }^{30}$ Fourth is the arrangement of marriages between countries by order (mail-order bride) where the bride does not know the actual condition of the prospective husband..$^{31}$ Fifth is the recruitment of children to become workers in several business units; in factories with low wages and working conditions that threaten their bodies' health, mental, and morals. ${ }^{32}$ Sixth, the infant's release without using the correct way and the legal process or due process of law..$^{33}$

In the case of human trafficking, it is not only related to human rights, but also other forms of crime such as illegal documents, torture, coercion, slavery, and embezzlement, where according to UNODC, these cases developed in line with the development of international mobility flows and economic needs. UNODC revealed that sex trafficking cases are the most dominant cases occurring globally with various forms of motives. ${ }^{34}$

\section{A. Sex Trafficking}

Sex trafficking is one of the forms of human trafficking that most happen in various countries in this world. Traffickers widely use sex trafficking to get women and children for sexual exploitation after doing money entrapment to the victims. It is argued that sex trafficking is the most extreme form of slavery in this modern era. It is because more than $54 \%$ of its victims are sexually exploited, according to the 2016 UNODC global report. ${ }^{35}$ Sex trafficking is further divided into several types, namely prostitution, online sex chat, pornographic content, and sex tourism.

having power over others, for exploitation. See Cathy Zimmerman \& Ligia Kiss, "Human Trafficking and Exploitation: A Global Health Concern"(2017) 14:11 PLoS Medicine. See also Ella Cockbain and Kate Bowers, supra note 19.

${ }^{29}$ Ibid.

30 Ibid.

31 Ibid.

32 Ibid.

33 Ibid.

34 Refworld, supra note 8.

35 Ibid. 
In terms of profit, sex trafficking can generate more than 99 million dollars globally. ${ }^{36}$ In the meantime, the most trafficked victims are women and children in a series of money fraud or kidnapping. In addition to the number of victims of sex trafficking among children alone is estimated at more than 1 million. ${ }^{37}$ From the mode of crime, the perpetrator of sex trafficking from various countries offers a permanent job interspersed with high wages to the victim and then "orders" from the victim's parents or family, even by coercion.

\section{B. Labor Trafficking}

Labor trafficking has become the most common form of human trafficking and also slavery in this modern era. There are more than 24.9 million people tied to this type of human trafficking. ${ }^{38}$ Usually, the victims are promised a more better-paid job or good opportunities by the perpetrators. However, instead of getting the job, they are instead sent to horrendous working conditions.

Victims are forced to work without any recognition of their rights as human beings. Labor trafficking has again been divided into three forms: bonded labor, child labor, and forced labor. ${ }^{39}$ Bonded labor is done by using debt bondage to the victims. There are no specified conditions and terms of service that must be done to pay off the victim's debt, which the perpetrator himself unworthily assesses in the form of victim service. In other words, who determines all this activity is not the victim but the perpetrator himself.

Child labor is the same prohibited activity as forced labor, but what distinguishes it is in the victims, child labor. The victims come from among those who are still minors or can be called children. In its practice, this kind of labor trafficking endangers the child's condition as the victim, whether it

${ }^{36}$ Jean Allain, "Genealogies of Human Trafficking and Slavery." In: Ryszard Piotrowicz, Conny Rijken, Baerbel Heide Uhl eds, Routledge Handbook of Human Trafficking (London, Routledge, 2017).

37 Ibid.

38 Ella Cockbain, and Kate Bowers, supra note 19.

39 Ibid. 
is their health, mental or educational condition. Forced labor is a job where the workers are forced to work in full threat, violence, and punishment. This kind of labor trafficking is carried out in a hidden place and away from public places. Tracking these places becomes more difficult to detect, full of inhumane behavior towards the workers, and over time this practice has become more widespread in other jurisdictions. Victims are also prohibited from going outside the working area into public areas, making them victims of confinement. The cause of forced labor quickly happens partly because of low wages or salaries, lack of regulations or control regarding proper working conditions, and the high demand for low-wage workers.

\section{Human Organ Trafficking}

Human trafficking is carried out in the field to enslave or exploit the victims who have been taken and harvest the victim's organs to be sold either to certain individuals or the black market. Human organ trafficking had become the most complex form of human trafficking, with a profit of 840 million until 1.7 billion dollars per year. ${ }^{40}$ It is estimated that more than $10 \%$ of all transplanted organs to be trafficked. ${ }^{41}$ The most trafficked organs were such as kidneys, lungs, livers, corneas, and hearts. In practice, the victims are forced to sell their organs for low prices through a mediator. It is not uncommon for many of them to be tempted by the offer due to the poverty factor experienced by most people. However, many of them had their organs stolen without their consideration. For example, they were unconscious when they were hospitalized.

\section{Forced Criminality}

Forced criminality also becomes the kind of human trafficking that uses elements of threat or coercion. Criminal actions such as ATM theft,

40 ILO, supra note 16.

41 Idil Atak \& James C. Simeon, "Human Trafficking: Mapping the Legal Boundaries of International Refugee Law and Criminal Justice" (2014) 12:5 Journal of International Criminal Justice 1019-1038. 
benefit fraud, forced begging, and pickpocketing becomes the types of crimes mostly forced on the victims..$^{42}$ However, other criminal types are forced on the victim outside these crimes. For example, in Latin America, many adults and children are forced to sell drugs by drug cartels. ${ }^{43}$

\section{E. Forced Marriages}

Forced marriages for certain countries are a common activity because of cultural reasons. Moreover, it is not often that the victims of this forced marriage get various violence perpetrated by a forced husband. However, many of the victims are still minors or children. It depends on the cultural relativity that adult women experience forced marriage.

\section{F. Mail-Order Bride}

Mail-order bride refers to purchase or service to victims through electronic mail media. The trick is that the buyer orders the product (female) desired via several methods, such as by telephone or website. One kind of mailborder bride can also be a forced marriage where the parents arrange the marriage. The mail-order bride can be considered an act of human trafficking sexually and economically through fraud, torture, and document retention. Its victims cannot escape from exploitation and the closure of access to information and communication with family. ${ }^{44}$

\section{G. Child Trafficking}

Child trafficking itself is not far from other forms of human trafficking that had been explained before, like sex trafficking, human organ trafficking, child labor, forced criminality, and forced marriage. However, in some

42 Ibid.

43 June S. Beittel, "Mexico: Organized Crime and Drug Trafficking Organizations," Congressional Research Services, online: <https://sgp.fas.org/crs/row/R41576.pdf>. See also IACHR, Violence, Children and Organized Crime (Inter-American Commission on Human Rights, 2016).

44 Ella Cockbain, and Kate Bowers, supra note 19. 
cases, the victims of child trafficking are often put on the battlefield as child soldiers. This case can be seen in conflict areas globally, mostly done by extremist groups.

\section{H. International Illegal Child Adoption}

The purpose of international illegal child adoption is actually for the interest of selling children to get profit. The victims of this criminal activity are children born from a hospital whose existence is not legally registered. Then, the victims are easily adopted only for the perpetrator's economic interests who are committing this crime. The perpetrator often bribes the authorities, law enforcers, and local government officials to get assistance in the form of approval of their fake documents. Those documents are one of the conditions that must be fulfilled to allow child adoption. ${ }^{45}$

\section{Household Slavery}

Household slavery is a follow-up effect of forced labor in which the victims are not only women and children but also men. Victims are taken from underdeveloped countries where the level of education of the people is still low. ${ }^{46}$ Therefore, with the limitations of knowledge that the victims have, they are easily swayed by the perpetrator's persuasion and become objects of household slavery. As that happens, like in forced labor, the perpetrator's mode in making the victim has no power to fight is to send them to a different country where the language is used in there is not the same as the victim's mother tongue. ${ }^{47}$

\section{J. Debt Bondage}

Debt bondage is also one of the forms of mode in human trafficking. This debt consists of the amount of money to be paid to families of victims and perpetrators, transport fees, bribe money given to officials or law enforcers,

45 Jackie Jones \& John Winterdyk supra note 18.

46 Ella Cockbain, and Kate Bowers, supra note 19.

47 Ibid. 
and the cost of living for the victim that the perpetrator bears with the worse cases is that the amount of money to be paid to the family and the perpetrator it turns out to be double and accompanied by the interest for each cost. ${ }^{48}$ To prevent the victim from running away before paying off their debts, the offenders usually put them in apartments guarded by guards or more, factories, perpetrators' homes, or brothels. However, if they try to escape, the victims are often deported to another country that uses a different language from the victim, the same as the household slavery case. ${ }^{49}$

\section{INTERNATIONAL LAW PERSPECTIVE ON HUMAN TRAFFICKING CASES}

International law has viewed human trafficking as an activity and a crime that must be immediately eradicated from the international community, threatening the world community's stability and security. This statement can be proven by international law itself had provided several regulations regarding human trafficking activities. The general view in international law regarding human trafficking has been included in the Universal Declaration of Human Rights (UDHR) as the milestone of human rights in modern times. Article 4 of the Declaration states that no shall be held in slavery or servitude: slave trade shall be prohibited in all their forms..$^{50}$ This Declaration explicitly emphasizes that slavery is one of the common enemies in the crime of human trafficking, where in some cases, slavery is often found in addition to other forms of human trafficking.

In the same context, the International Covenant on Civil and Political Rights (ICCPR) stated the same in the UDHR. Article 8 outlines that no one shall be held in slavery; Slavery the slave trade in all their forms shall be prohibited. ${ }^{51}$ From the two provisions before, it is clear that from the provision in Article 4 of the UDHR and Article 8 of the ICCPR, all forms of slavery are acts that must be stopped and prohibited. However, the definition or term of "slavery" itself in those two provisions is not explained

48 Jackie Jones \& John Winterdyk supra note 18.

49 Ibid.

50 Article 4 of the Universal Declaration of Human Rights (UDHR).

51 Article 8 of International Covenant on Civil and Political Rights (ICCPR). 
clearly. The definition of slavery is expressly stated in the Slavery Convention 1926 as a condition of a person over whom any or all powers attaching to ownership rights are exercised. ${ }^{52}$ However, this definition is still extensive, covering various interpretations of the practice of slavery.

This definition gives the important impression that slavery also includes the actions of selling, buying, and transporting certain people to do exploitation to generate a profit from the actions. ${ }^{53}$ According to the definition of slavery in the 1926 Convention of Slavery, it is clear that human trafficking can be categorized as an act of slavery. It is because human trafficking activities also include the actions that are mentioned in the definition above. Certain people are sold, bought, and transported to another country by some parties to be exploited according to the forms of human trafficking, whether it is exploited sexually, physically, or other kinds of exploitation.

The international Convention has regulated human trafficking activities for a long time. Since the early 20th Century, these conventions have been initiated when the act of trafficking in persons entered a transitional period between the old and modern types of human trafficking. Examples of these conventions are like International Agreement for the Suppression of White Slave Traffic 1904, the International Convention for the Suppression of White Slave Traffic 1910, the International Convention for the Suppression of White Slave Traffic 1921, International Convention for the Suppression of Traffic in Women and Children 1921 and International Convention for the Suppression of Traffic in Women of Full Age 1933. On its basis, these conventions wanted an active role of the state in preventing, protecting, and enforcing the law against human trafficking activities in its country. ${ }^{54}$ The 1921 Convention for the Suppression of White Slave Traffic is the emergence of two existing international legal provisions, namely the 1904 Agreement and the 1910 Convention for the

521926 Convention of Slavery.

53 Deypend Tommy Sibuea, "Pemberantasan Perdagangan Orang Melalui Instrumen Hukum Nasional dan Hukum Internasional di Indonesia" (2018) 3:2 JCH (Jurnal Cendekia Hukum).

54 Nicole Siller, "Human Trafficking in International Law Before the Palermo Protocol" (2017) 64:3 Netherlands International Law Review 407-452. 
Suppression of the White Slave Traffic, which both discusses the issue of white slavery that occurs in Europe at the end of $19^{\text {th }}$ Century.

\section{A. The 1904 Agreement for the Suppression of the White Slave Traffic}

The purpose of establishing the 1904 Agreement as the early stage in eradicating human trafficking activity is to fulfill the international aspiration for an effective crackdown on white slave traffic as the criminal traffic. The 1904 agreement has several functions in its services which cover administrative function by establishing an agreement to monitor existing phenomena and contrary to requiring legislative action that includes mandatory criminalization of what has been termed "white slavery" as a domestic crime. ${ }^{55}$

For this purpose, the 1904 Agreement focuses on the states' commitment to formulate measures related to victim identification, gathering information that could lead to criminal investigations, monitoring railway stations, ports of embarkation and ports of travel, and personnel training. Thus, these steps allow them to detect victims of trafficking. In addition, the agreement also calls on the countries concerned under the agreement to provide repatriation assistance to identified victims and provide security and jobs. Although the 1904 Agreement referred to the criminal traffic and the white slave trade, the document or preparatory work inside it did not clearly explain the legal implications of these concepts.

However, the 1904 Agreement had become the first international legal basis of human trafficking actions. Article 1 states that the governments of each state party to the agreement undertake to establish or appoint a competent authority to coordinate all information regarding the procurement of women or girls for unethical purposes abroad. This body will have direct links with similar bodies established in other countries on the agreement. ${ }^{56}$ The 1904 Agreement only regulates trafficking between countries or states. It does not include intrastate transport and trafficking between the country and its colonies, which was still a lot at that time. It is

55 Ibid.

56 Article 1 of the 1904 Agreement. 
an obvious choice designed to balance the desire to oppose the white slave trade while respecting the domestic jurisdiction over each country's national sovereignty.

\section{B. The 1910 Convention for the Suppression of White Slave Traffic}

After establishing the 1904 Agreement, the eradication against white slave traffic is continued with the 1910 International Convention for the Suppression of White Slave Traffic. Although this Convention updates the previous Convention, this Convention's overall content does not conflict with the last white slave traffic convention, namely the 1904 Agreement. This second international law's main objective is to promote the criminalization of human trafficking in the country. In particular, it is considered by the representatives of the 1910 conference that the agreement held before is not effective in imposing the state obligations to regulate criminal offenses. The administrative measures could not deal with the white slavery problem as one of the forms of trafficking in persons. ${ }^{57}$ This Convention is closely related to the practice of slavery in the prostitution sector at that time.

This Convention's critical point is that the 1910 Convention is the first international Convention to consider human trafficking as a transnational crime. The concept of trafficking in persons or human trafficking from the 1910 Convention still requires two elements. The first element is the acquisition, which is stipulated in Article 1 or 2 of the Convention to achieve the second element, namely immoral goals. ${ }^{58}$ In dividing the types of offense in human trafficking activity, the 1910 Convention divides it into two types of offense. Human trafficking involves underage children and an offense that occurs in human trafficking involving adult women.

In particular, Article 1 excludes underage girls' defense because it states that "even with consent" is a crime of trafficking in persons. However, Article 2 does not include the term "women over the age." Therefore, it is

\footnotetext{
57 Jean Allain, "White Slave Traffic in International Law" (2017) 1:1 Journal of Trafficking and Human Exploitation 1-40.

58 Ibid.
} 
necessary to show compulsion to reject one's consent to achieve the first element. ${ }^{59}$ Ultimately, however, based on paragraph B of the Final Protocol, the 1910 Convention clarifies that 'Women or girls underage' include women aged 20 years or younger. In contrast, women's overage refers to women aged 21 years or over. During the 1910 conference, the disagreement of several countries in the Convention, such as Germany, escalated into a heated debate because they believed that age limits should be determined by the country where human trafficking occurred. The 1910 Convention also referred to white slave traffic as women recruited for prostitution abroad. However, the 1910 Convention provides considerations even though it is still minimal about a person classified as a victim and actions categorized as human trafficking.

\section{The 1921 Convention for the Suppression of Traffic in Women and Children}

Apart from white slavery traffic as a form of human trafficking in the early 1900s, trafficking against women and children also became a problem. The 1921 Convention for the Suppression of Traffic in Women and Children is established, approved by 34 countries or states. The 1921 Convention was explicitly designed to complement the two pre-existing international trade instruments to eliminate trafficking in women and children. In terms of the categorization of victims, this Convention does not consider victims of their race or skin color. Child victims are no longer viewed from their gender, both female and male. ${ }^{60}$ This Convention as a legal instrument aimed to strengthen the protection for girls who are still underage and children of both females and males with adult women is no longer included in this Convention.

In implementing the 1921 Convention, member states agreed to report on the steps that have been taken by the countries concerned in taking action against human trafficking periodically to prove their commitment to this

59 Article 1 and 2 of the 1910 Convention.

60 Nicole Siller, '"Modern Slavery': Does International Law Distinguish Between Slavery, Enslavement, and Trafficking?" (2016) 14:2 Journal of International Criminal Justice 405-427. 
Convention. Then, as the advisory committee, the League of Nations established the 1927 Report as the essence of all reports submitted in the previous years, which determine four types of traffickers, among others, principals, mesdames, souteneurs, and intermediaries. ${ }^{61}$ Principals are the one who usually owns the brothel as the "cage" of human trafficking activity, which is also seen as influential individuals. Mesdames is the one who manages the brothel that the principals own. Souteneurs are the ones who live on and from the earnings of one girl or more that were under his control. Furthermore, the intermediaries are the ones who have the task of securing and transporting the girls to mesdames or souteneurs. Thus, this report had become the first international report to formally disclose and transcribe an international perspective on the actual meaning of human trafficking, in this regard as a perverted mechanism for the collection and transport of prostitutes or women and girls for the interest of prostitution activity. ${ }^{62}$ Discussion about human trafficking activity that involved women of full age is discussed in the following international Convention.

\section{The 1933 Convention for the Suppression of Traffic in Women of Full Age}

The International Convention for the Suppression of Traffic in Women of Full Age of 1933 continues the 1921 International Convention for the Suppression of Traffic in Women and Children; this Convention gave regulations concerning human trafficking activity that involve women of full age. After establishing the 1921 Convention, the world community gave attention even more to human trafficking that happened in prostitution activities. The previous 1927 Report has also influenced the creation of this 1933 Convention in providing an internationally applicable definition of human trafficking and improving the legislative scope of human trafficking. In Article 1 of the 1933 Convention provisions, the Convention extending the punishable requirements for trafficking in persons includes attempted violation and preparatory action for the

\footnotetext{
${ }^{61}$ Foo Yen Ne, "Human Trafficking: In the Shadows of the Law" (2018) S. Rajaratnam School of International Studies, online <http://www.jstor.org/stable/resrep26880>.

${ }^{62}$ Ibid.
} 
intended offense within legal limits. Besides, the term "state" in this Convention includes the colonies and protectorates of the parties concerned and the territories under them. ${ }^{63}$

\section{E. The 1979 Convention on the Elimination of All Form of Discrimination Against Women}

The 1979 Convention on the Elimination of All Form of Discrimination against Women (CEDAW) was established at the time when the issue of trafficking in persons re-emerged along with the increasing attention to women's human rights, then trafficking in persons especially trafficking in women, has become an international world concern. This Convention is also widely regarded as the charter of international rights for women.

This Convention defines human rights, norms, and standards of behavior and obligations that States parties to the Convention agree to fulfill. In general, this Convention provides a basic framework for equality between men and women. States that accept this Convention must commit to taking steps to eradicate discrimination against women of all kinds. First, it includes the principle of gender equality in their respective national legal systems by eliminating all discriminatory laws by adopting or enacting laws against acts of discrimination against women. Second, it establishes courts and other public institutions to ensure adequate protection of women from discrimination. Third, it ensures the elimination of all acts of discrimination against women by persons, organizations, or companies. ${ }^{64}$ With the acceptance of this Convention, women's treatment, mostly arbitrary acts, including the trafficking of women and gender discrimination, can be overcome. With the establishment of this Convention, state parties are expected to eliminate discrimination against women. They also can serve as the basis to make appropriate laws and implement this Convention as a form of respect for the agreement produced by the parties to the Convention.

63 Article 1 of the 1933 International Convention for the Suppression of Traffic in Women of Full Age.

${ }^{64}$ Lourensy Varina Sitania \& Eko Suponyono, supra note 2. 


\section{F. The UN Protocol against Transnational Organized Crime}

Besides international conventions, international protocols regulate human trafficking activity as a form of transnational crime. One of them is the 2000 UN Protocol against Transnational Organized Crime. This kind of protocol had provided precise protection for victims of human trafficking in the early days of modern human trafficking. The UNTOC protocol also regulates the protection of victims in the recipient country and the repatriation to their countries. ${ }^{65}$

The ultimate goal of trafficking in persons, according to the UNTOC convention, is exploitation. It asserts that action with or without the consent of the victim which includes and is not limited to prostitution, forced labor or service, slavery or similar practices of slavery, oppression, extortion, both physically and sexually, reproductive organs exploitation, or illegally transferring power or transplanting organs and/or body tissue or using someone else's power or ability to gain an advantage, both material and immaterial.

\section{G. Palermo Protocol}

After establishing the UN Protocol against Transnational Organized Crime, there is also a protocol regarding human trafficking activities that continue the UNTOC Protocol, which had been previously found regulated in the 2000 Palermo Protocol. The Palermo Protocol provided a clearer view and effort to protect victims of human trafficking than the UNTOC Protocol. 169 countries have ratified the protocol, indicating that they are willing to engage in trafficking in persons. ${ }^{66}$ In the protocol, countries emphasized taking effective action in preventing and combating trafficking in persons. It is necessary to adopt a comprehensive international approach in countries of origin, transit, and destination. Accordingly, this protocol aims to establish a framework to help define

65 Yuda Prasetya, supra note 14.

66 Elżbieta M. Goździak \& Kathleen M. Vogel, "Palermo at 20: A Retrospective and Prospective" (2020) 6:2 Journal of Human Trafficking 109-118. 
what trafficking is, prevent trafficking, and assist countries in their joint efforts to solve trafficking in persons. ${ }^{67}$

This protocol also creates an annual global report regarding human trafficking activities called the UN Global Plan of Action to Combat Trafficking in Persons, established by the UN Office on Drugs and Crime. With this report, everyone can observe human trafficking actions yearly, which also helps eradicate and caution the global community against human trafficking activities. According to the Global Report, the impact of the Palermo Protocol has made $95 \%$ of member countries that ratified the protocol. This ratification means that member countries have legal legislation to eradicate human trafficking to anticipate, minimize and punish human traffickers, especially in the types of human trafficking involved, where women and children are victimized under this protocol. ${ }^{68}$

Currently, the state assists victims to accommodate and then return or repatriate the victims of human trafficking with funds and costs by the recipient country. Especially for victims who then get into legal problems, the country of origin can help its citizens get the justice they deserve. Unlike other international legal instruments that emphasize the aspects of human rights in eradicating human trafficking and providing protection for victims of human trafficking, the Palermo Protocol does not stick to the human rights aspect. However, it emphasizes facilitating collaboration and cooperation between countries or states in eradicating human trafficking as part of organized crime. The Palermo Protocol distinguishes trafficking and smuggling in three crucial aspects: consent, exploitation, and transnationality. Smuggling involves immigrants who agree to be smuggled.

On the other hand, trafficking victims never consent to this activity, but if they agree initially, the agreement becomes meaningless through coercion,

67 Savanne Estourgie, "The fight against Human Trafficking: Why Do Countries Ratify, But Not All Comply with the Palermo Protocol?" (2016) Student Thesis., Radboud University Faculty of Management.

68 Elżbieta M. Goździak \& Kathleen M. Vogel, supra note 66. 
fraud, or harassment from the trafficker. ${ }^{69}$ Smuggling usually ends when the migrants reach their destination, while trafficking involves the victim's continued exploitation. It is generally believed that victims of trafficking are often more affected than smuggled migrants and need more protection to avoid further sacrifice. However, empirical data do not support this difference. Also, the question remains about how to measure the level of exploitation and suffering of these two groups. The last aspect is that smuggling is always included as a transnational crime. In contrast, human trafficking can occur in the victim's country of origin does not have to occur between countries or continents.

In other words, the Palermo Protocol can focus more on combatting crime and not dealing with the victims of the crime. Its provisions can be proven, which emphasizes the interception, punishment, and prosecution of traffickers. In its implementation, member states of this protocol have shown their commitment to eradicating human trafficking and increasing preventive efforts.

\section{H. International Convention on the Rights of the Child}

The problems of children as victims of human trafficking should not go unnoticed. The International Convention on the Rights of the Child outlines that every state should protect children from all kinds of exploitation or employment. It could result in damage or interfere with a child's education process or threaten the physical, mental, spiritual health of children and the development of other social services, according to Article 32 of the Convention. ${ }^{70}$ Furthermore, Article 35 of the same Convention states that the government is obliged to make multilateral measures to prevent child kidnapping and trafficking for any purpose and provide social service programs and provide full support to every child in their life. ${ }^{71}$ Therefore, in other words, this Convention encourages

69 Ryszard Wilson Piotrowicz \& Liliana Sorrentino, "Human Trafficking and the Emergence of the Non-Punishment Principle" (2016) 16:4 Human Rights Law Review 669-699.

70 Articles 32 of the International Convention on the Rights of the Child.

71 Article 35 of the International Convention on the Rights of the Child. 
international cooperation for handling human trafficking cases in both prevention and enforcement processes.

\section{J. ILO Convention 182 on the Probibition and Immediate Action for the Elimination of the Worst Forms of Child Labor}

In eradicating human trafficking against children, international law provides a convention issued by the International Labor Organization (ILO). It is stipulated in the ILO Convention Number 182 concerning the Prohibition and Immediate Action for the Elimination of the Worst Forms of Child Labor. In this Convention, the worst forms of child labor include all forms of slavery or practices similar to slavery, the use of children for pornography and porno-action activities, the use of children for the production and distribution of illegal drugs, and all forms of work that can interfere the health, safety or morals of children. ${ }^{72}$ The main feature of this Convention states that all children aged under 18 years must be protected from the worst forms of child labor and oblige member states to take steps to eliminate the worst forms of child labor and forced labor, as mentioned above. $^{73}$

For the Convention to be implemented more effectively by each country, it is necessary to ratify the Convention into the national law of each country. Countries that ratified this Convention should have a responsive and effective action against all forms of work aimed at exploiting children, followed by regulating the types of work included in the worst criteria for child labor. Consequently, it can divide between good and bad work for children in concerning countries. The countries involved shall take steps to ensure that the provisions of this Convention can be applied effectively within their country.

72 Darious Mahendra N, et al., "Implementasi Konvensi ILO Nomor 182 Tahun 1999 dalam Menanggulangi Permasalahan Pekerja Anak Korban Perdagangan Manusia di Indonesia" (2018) 6:1 Kertha Negara: Journal Ilmu Hukum.

73 Ibid. 


\section{HOW DO INTERNATIONAL LEGAL INSTRUMENTS DEAL WITH HUMAN TRAFFICKING?}

The most important international instrument to combat trafficking is the Palermo Protocol, supplementing the UN Convention against Transnational Organized Crime (2000). Article 5 of the Protocol requires States to criminalize trafficking, attempted trafficking, and any other intentional participation or organization in a trafficking scheme. Two International Labour Organization (ILO) conventions focus on forced labor or services: The ILO Forced Labour Convention (Convention No. 29 of 1930) and its newly adopted Protocol, which defines forced or compulsory labor, and the ILO Abolition of Forced Labour Convention (Convention No. 105 of 1957). The Slavery Convention (1926) defines slavery, and its Supplementary Convention describes "practices similar to slavery," including debt bondage and institutions and practices that discriminate against women in the context of marriage. The UN Convention for the Suppression of the Traffic in Persons and the Exploitation of the Prostitution of Others (1949) requires States to punish any person who exploits prostitution. The International Covenant on Civil and Political Rights (ICCPR) prohibits several practices directly related to trafficking, including slavery, the slave trade, servitude, and forced labor.

The Convention on the Elimination of All Forms of Discrimination against Women requires States to take all appropriate measures to suppress all forms of trafficking in women and women's exploitation for prostitution. General recommendation No. 19 identifies trafficking as a form of violence against women because it puts women at special risk of violence and abuse. Trafficking is incompatible with women's equal enjoyment of rights and with respect for their rights and dignity.

Some international instruments have specific provisions concerning the trafficking of children. The Convention on the Rights of the Child (1989) and the Optional Protocol on the Sale of Children, Child Prostitution, and Child Pornography (2000) prohibit trafficking in children for any purpose, including exploitive and forced labor. Article 39 of the CRC requires States to take all appropriate measures to promote physical and psychological 
recovery and social reintegration of a child victim of any form of neglect, exploitation, or abuse. The CRC also requires States to recognize the right of every child to education (Article 28) and "to facilities for the treatment of illness and rehabilitation of health" (Article 24). The Optional Protocol to the Convention on the Sale of Children specifies particular protection and assistance available to child victims.

Additionally, the ILO's Worst Forms of Child Labour Convention (Convention No. 182 of 1999) prohibits perpetrators from using children under 18 years of age for all forms of slavery or practices similar to slavery, trafficking, debt bondage, serfdom, forced or compulsory labor, and prostitution. Article 7(2)(b) and (c) requires States to take effective and timely measures to provide for the rehabilitation and social integration of former victims of the worst forms of child labor. They include trafficking and ensuring their access to free primary education and, wherever possible and appropriate, vocational training.

Some instruments contain specific provisions for addressing the needs of foreign victims. For example, Article 7 of the Palermo Protocol says States should consider potential measures for allowing foreign trafficking victims to remain, temporarily or permanently, in the state in which they were trafficked. The UN High Commissioner for Refugees (UNHCR) has noted that some people who have been trafficked or who are at risk of being trafficked may be entitled to international refugee protection under the Convention relating to the Status of Refugees (1951) and its 1967 Protocol if they have a well-founded fear of persecution for reasons of race, religion, nationality, membership of a particular social group or political opinion.

Article 8 of the Palermo Protocol deals with the possible repatriation of trafficking victims. It notes that when a State returns a victim, it should do so with due regard for that person's safety. Repatriation "shall preferably be voluntary." A person's right to return to his or her country of origin is affirmed by the International Covenant on Civil and Political Rights. Additionally, the International Convention on the Protection of the Rights of All Migrant Workers and Members of their Families (1990) expands the 
rights of migrant workers and calls upon States to protect their rights as reflected in Article 68 effectively.

While the international norms are clear, gaps remain existing in the implementation. Although the Palermo Protocol calls for a comprehensive approach to combat trafficking, this approach has not been fully realized. States often attempt to address trafficking from only an immigration perspective or a solely criminal perspective. States must recognize and implement all the international instruments to combat trafficking to ensure that the problem is dealt with to the fullest extent possible. A human rights-based approach to addressing trafficking gives equal attention to prevention, protection, and prosecution. This victim-centered approach requires collaboration between legislators, prosecutors, law enforcement, service providers, and other victim advocates.

\section{CONCLUSION}

Human trafficking has become one of the most serious criminal activities that must be eradicated immediately from this world. Human trafficking consists of many forms, which include sex or sexual exploitation, labor trafficking, human organ trafficking, forced criminality, forced marriages, mail order bride, child trafficking, international illegal child adoption, household slavery, and debt bondage. In terms of eradicating and preventing human trafficking, there are already some regulations on trafficking in persons internationally. These international laws have provided specific and general arrangements regarding human trafficking, which are again divided into respective discussion topics. Some focus on white slavery in the early 20th Century, as in the 1904 Agreement and 1910 Convention for the Suppression of White Slave Traffic. Others focus on matters like the protection of women and children from human trafficking as in the 1921 and 1933 Convention, the enforcement of women's right in dealing with human trafficking as in CEDAW, more focus on the eradication of human trafficking as in UNTOC Protocol and Palermo Protocol and the eradication of child's trafficking. Given how dangerous human trafficking is, the countries should be aware of this 
problem and unite to cooperate and work together to prevent and eradicate it even though various international law types can be used directly against human trafficking. With these various laws and regulations, it is appropriate for every country in the world to immediately implement those laws and regulations in their respective countries so that if this condition occurs, every human trafficking perpetrator can be entangled in own actions. Thus, every victim can be free from the entanglement of human trafficking, the wider community, and global stability can be protected from human trafficking activities. Thus, the world can finally be free from human trafficking activities.

\section{ACKNOWLEDGMENTS}

None.

\section{COMPETING INTERESTS}

The authors declared that they have no competing interests.

\section{REFERENCES}

Allain, Jean, "Genealogies of Human Trafficking and Slavery." In: Ryszard Piotrowicz, Conny Rijken, Baerbel Heide Uhl eds, Routledge Handbook of Human Trafficking (London, Routledge, 2017).

Allain, Jean, "White Slave Traffic in International Law" (2017) 1:1 Journal of Trafficking and Human Exploitation 1-40.

Arief, Eva, "Relevansi Hukum Pidana Internasional dalam Menganalisis Kasus Perdagangan Manusia Khususnya Wanita dan Anak-Anak, Sebagai Salab Satu Jenis Kejahatan Transnasional" (2016) 4:1 Hukum dan Dinamika Masyarakat 89-97.

Atak, Idil \& James C. Simeon, "Human Trafficking: Mapping the Legal Boundaries of International Refugee Law and Criminal Justice" (2014) 12:5 Journal of International Criminal Justice 1019-1038.

Beittel, June S., "Mexico: Organized Crime and Drug Trafficking Organizations," Congressional Research Services, online: <https://sgp.fas. 
org/crs/row/R41576.pdf>. See also IACHR, Violence, Children and Organized Crime (Inter-American Commission on Human Rights, 2016).

Blom, Nadine, "Human Trafficking: An International Response."In: Winterdyk J., Jones J. (eds), The Palgrave International Handbook of Human Trafficking (Cham: Palgrave Macmillan, 2020).

Chuang, Janie, "Exploitation Creep and the Unmaking of Human Trafficking Law" (2014) 108:4 American Journal of International Law 609-649.

Cockbain, Ella \& Kate Bowers, "Human Trafficking for Sex, Labor, and Domestic Servitude: How Do Key Trafficking Types Compare and What are Their Predictors?" (2019) 72:1 Crime, Law, and Social Change 934.

Dergi, Hakemli, Galatasaray Üniversitesi Hukuk Fakültesi Dergisi (Istambul: Beta Basim Yayim Dağitim, 2019).

Dovydaitis, Tiffany, "Human Trafficking: The Role of the Health Care Provider" (2010) 55:5 Journal of Midwifery Women's Health 462467.

Estourgie Savanne, "The fight against Human Trafficking: Why Do Countries Ratify, But Not All Comply with the Palermo Protocol?" (2016) Student Thesis., Radboud University Faculty of Management.

FBI, "Human Trafficking," online: <https://www.fbi.gov/investigate/violentcrime/ human-trafficking>.

Gillette, Jane, "Human Trafficking" (2012) 143:8 Journal of the American Dental Association 830.

Goździak, Elżbieta M. \& Kathleen M. Vogel, "Palermo at 20: $A$ Retrospective and Prospective" (2020) 6:2 Journal of Human Trafficking 109-118.

Harpur, Paul \& Heather Douglas, "Disability, Domestic Violence, and Human Rights." In: Reilly N. (eds), International Human Rights of Women (Singapore: Springer, 2019).

Högfors, Frida, "Human Trafficking International Law and the Regulation of Sexual Exploitation of Women on the Internet" (2020) Student Thesis, Örebro University, School of Law, Psychology and Social Work.

ILO, Global Estimates of Modern Slavery: Forced Labour and Forced Marriage (Geneva: International Labour Office, 2017). 
Jones, Jackie \& John Winterdyk, "Introduction Human Trafficking: Challenges and Opportunities for the 21st Century" (2018) 8:1 Oñati Socio-Legal Series 1-10.

Mahendra N, Darious, et al., "Implementasi Konvensi ILO Nomor 182 Tahun 1999 dalam Menanggulangi Permasalahan Pekerja Anak Korban Perdagangan Manusia di Indonesia" (2018) 6:1 Kertha Negara: Journal Ilmu Hukum.

Ne, Foo Yen, "Human Trafficking: In the Shadows of the Law" (2018) S. Rajaratnam School of International Studies, online <http://www. jstor.org/stable/resrep26880>.

Novianti. "Tinjauan Yuridis Kejahatan Perdagangan Manusia (Human Traffikking) sebagai Kejahatan Lintas Batazzs Negara"(2014) 5:2 Jurnal Ilmu Hukum Jambi.

Online Interpol International, "286 arrested in global buman trafficking and migrant smuggling operation", online: <https://www.interpol.int/Newsand-events/news/2021/286-arrested-in-global-human-trafficking-and -migrant-smuggling-operation>.

Piotrowicz, Ryszard Wilson \& Liliana Sorrentino, "Human Trafficking and the Emergence of the Non-Punishment Principle" (2016) 16:4 Human Rights Law Review 669-699.

Polaris, "US National Human Trafficking Hotline", online: <https:// polarisproject.org/resources/us-national-human-trafficking-hotlinestatistics/>.

Prasetya, Yuda, "Legal Analysis of Human Trafficking Case as A Transnational Organized Crime That is Threatening State Security" (2020) 4:1 Lex Scientia Law Review 143-150.

Putri, Anggie Rizqita Herda \& Ridwan Arifin, "Perlindungan Hukum Bagi Korban Tindak Pidana Perdagangan Orang di Indonesia" (2019) Res Judicata 2:1: 170-185.

Refworld, "UN Office on Drugs and Crime Global Report," online: <https:// www.refworld.org/publisher,UNODC,IND,,0.html>.

Republika Online, "Kasus Perdagangan Orang di Indonesia Naik Pada 2020", online: <https://www.republika.co.id/berita/qr7v11330/kasusperdagangan-orang-di-indonesia-naik-pada-2020>. 
Sibuea, Deypend Tommy, "Pemberantasan Perdagangan Orang Melalui Instrumen Hukum Nasional dan Hukum Internasional di Indonesia" (2018) 3:2 JCH (Jurnal Cendekia Hukum).

Siller, Nicole, "Human Trafficking in International Law Before the Palermo Protocol" (2017) 64:3 Netherlands International Law Review 407-452.

Siller, Nicole, "'Modern Slavery': Does International Law Distinguish Between Slavery, Enslavement, and Trafficking?" (2016) 14:2 Journal of International Criminal Justice 405-427.

Simmons, Beth A., et al., "The Global Diffusion of Law: Transnational Crime and the Case of Human Trafficking" (2018) 72:2 International Organization 249-281.

Sitania, Lourensy Varina \& Eko Suponyono, "Akomodasi Pemberantasan Tindak Pidana Perdagangan Orang dalam Aspek Hukum Internasional dan Nasional" (2020) 2:1 Jurnal Pembangunan Hukum Indonesia 3854.

Sundari, Endah, Analisis Yuridis Terhadap Bali Declaration on People Smuggling, Trafficking in Persons And Related Transnational Crime Sebagai Salah Satu Bentuk Perjanjian Internasional (2017) Student Thesis, Universitas Sumatera Utara Faculty of Law.

UNHR, Human Rights and Human Trafficking" United Nations (New York: UNHR, 2014).

UNODC, "An Introduction to Human Trafficking: Vulnerability, Impact, and Action (New York: United Nations, 2008).

UNODC, Global Report on Trafficking in Persons 2020 (New York: UNODC, 2020).

US Embassy, "2020 Trafficking in Persons Report", online: <https://id. usembassy.gov/our-relationship/official-reports/2020-trafficking-inpersons-report/>.

Zimmerman, Cathy \& Ligia Kiss, "Human Trafficking and Exploitation: A Global Health Concern" (2017) 14:11 PLoS Medicine. 